\title{
Preparation and antimicrobial activity of 'Yuja' nanoemulsion using ultrasonic homogenization treated 'Yuja' juice
}

\author{
Seo A Jung ${ }^{1}$, Su Jung Hong ${ }^{2}$, Jun Tae $\mathrm{Kim}^{2}$, Su-Hyeon Kim³ , \\ Mi-Kyung Park ${ }^{3}$, Dong Hee Lee ${ }^{4}$, Gye Hwa Shin ${ }^{1 *}$ \\ ${ }^{1}$ Department of Food and Nutrition, Kunsan National University, Gunsan 54150, Korea \\ ${ }^{2}$ Department of Food Science and Technology, Keimyung University, Daegu 42601, Korea \\ ${ }^{3}$ School of Food Science and Biotechnology, Kyungpook National University, Daegu 41566, Korea \\ ${ }^{4}$ Korea Natural Food Co. Ltd., Jeonju 54809, Korea
}

\section{초음파처리 유자즙을 이용한 유자 나노에멀젼 제조 및 항균 특성}

\author{
정서아 ${ }^{1} \cdot$ 홍수정 $^{2} \cdot$ 김준태 $^{2} \cdot$ 김수현 $^{3} \cdot$ 박미경 $^{3} \cdot$ 이동희 $^{4} \cdot$ 신계화 $^{1 *}$ \\ ${ }^{1}$ 군산대학교 식품영양학과, ${ }^{2}$ 계명대학교 식품가공학과, \\ ${ }^{3}$ 경북대학교 식품공학부, ${ }^{4}$ 고려자연식품(주)
}

\begin{abstract}
Oil-in-water $(\mathrm{O} / \mathrm{W})$ 'Yuja' nanoemulsion was successfully prepared using 'Yuja' juice as an aqueous phase and 'Yuja' seed oil as an oil phase. 'Yuja' nanoemulsion was further coated using chitosan solution to improve its stability. Firstly, 'Yuja' oils were extracted from traditionally wasted 'Yuja' seeds by using supercritical carbon dioxide extraction technique. The mean particle diameter of 'Yuja' nanoemulsion was $145.6 \mathbf{~ n m}$ and significantly $(p<0.05)$ decreased to $79.5 \mathrm{~nm}$ after chitosan coating. The shape of 'Yuja' nanoemulsion droplets was heterogeneous with some round and rod shapes whereas chitosan-coated 'Yuja' nanoemulsion showed homogenous droplets with spherical shape and uniform distributions. Antimicrobial activity of ultrasonic homogenized 'Yuja' juice (UH-'Yuja' juice), 'Yuja' nanoemulsion ('Yuja' NE) and chitosan-coated 'Yuja' nanoemulsion (CS-'Yuja' NE) was evaluated against Staphylococcus aureus and Escherichia coli at $25^{\circ} \mathrm{C}$ and $10^{\circ} \mathrm{C}$ in every $2 \mathrm{~h}$ up to $12 \mathrm{~h}$. Antimicrobial activity of UH-'Yuja' juice, 'Yuja' NE, and CS-'Yuja' NE was significantly $(p<0.05)$ different compared to the negative control (PBS) both at $25^{\circ} \mathrm{C}$ and $10^{\circ} \mathrm{C}$ and similar to the positive control (Ampicillin) at $10^{\circ} \mathrm{C}$. These results showed that CS-'Yuja' NE had higher antimicrobial activity than UH-'Yuja' juice and 'Yuja'-NE against Staphylococcus aureus and Escherichia coli.
\end{abstract}

Key words : 'Yuja' juice, 'Yuja' seed oil, nanoemulsion, chitosan, antimicrobial, ultrasonic homogenization

서 론

유자(Citrus junos)는 운향과 감귤속으로 분류되는 잡종 재배식물로 비타민 $\mathrm{C}$, 구연산, 카로틴, 헤스페리딘 성분을 다량 함유하고 있으며(Kang 등, 2006), 폴리페놀과 플라보
노이드 성분들도 함유하고 있어 면역활성이나 항염증 및 항산화 기능이 있는 것으로 보고되었다(Yoo와 Hwang, 2004; Kim 등, 2010). 유자는 숙성 정도에 따라 녹색 또는 황색을 띄며, 특유의 향이 강하고 신맛이 강하여 유자청으 로 가공 후 차 형태로 대부분 이용되고, 막걸리와 같은

*Corresponding author. E-mail : winnie19@kunsan.ac.kr, Phone : +82-63-469-4634, Fax : +82-63-469-2085

Received 16 December 2019; Revised 30 December 2019; Accepted 19 February 2020.

Copyright (c) The Korean Society of Food Preservation.

This is an Open Access article distributed under the terms of the Creative Commons Attribution Non-Commercial License (http://creativecommons.org/licenses/by-nc/4.0) which permits unrestricted non-commercial use, distribution, and reproduction in any medium, provided the original work is properly cited. 
주류 가공에도 이용되었다(Yang 등, 2011). 유자는 다른 과일과는 달리 산업적으로 과피를 주로 이용하고, 유자즙 의 이용은 미비한 실정이며, 유자 총 중량의 $15 \%$ 에 달하는 유자씨는 대부분 폐기처분 되는 실정이다(Lee 등, 2017). 유자와 함께 citrus fruits에 포함되는 자몽씨 추출물은 탁월 한 항산화력과 항균력을 가진 것으로 알려져 있으며, 일부 연구에서는 유자과즙 추출물의 항균력에 대한 연구 보고 서를 발표하였다(Lee와 Lee, 2017). 하지만 유자씨를 이용 한 식품원료로서의 적용이나 이들의 생리활성 등에 관한 연구는 거의 미흡한 실정이다.

천연의 소재에서 오일을 추출함에 있어, 증류법이나 유 기용매를 이용하여 추출하는 방법은 열을 가하는 공정이 추가되어 유효성분의 변성을 일으킬 수 있다. 또한, 식품 에 적용하기 위해서는 잔존 용매의 위험성으로 인하여 다시 용매를 휘발시켜야 하는 번거로움이 있을 수 있고, 사용된 유기용매의 폐기처리로 환경오염을 유발할 수 있 다는 문제점이 있다(Jo 등, 2018). 반면 초임계 이산화탄소 추출법은 유체의 임계점 근방 또는 그 이상의 온도와 압력 하에 유체의 특이적 성질을 이용하여 유용물질을 추출하 는 방법으로 비교적 낮은 온도 $\left(40-60^{\circ} \mathrm{C}\right)$ 에서 수행되므로 열에 민감한 천연물질의 분리 - 정제에 많이 이용되고 있 으며, 용매 추출법에 비해서 용매의 회수가 용이하고, 독 성이 없기 때문에 식품, 화장품, 의약품에 널리 사용되고 있다(Lee 등, 2002). 초임계 이산화탄소 추출법은 기존 용 매추출법과 비교하여 추출 시간이 짧고, 무색, 무독성, 불 연성 등의 특징을 가지며, 특히 용질과 반응을 하지 않으 므로, 유효 성분의 변성을 일으키지 않는 등의 다양한 장 점을 가진다(Lee 등, 2002; Jo 등, 2018). 그러므로 유자씨 에서 오일을 추출할 수 있는 여러 가지 방법 중 초임계 이산화탄소 추출법은 오일의 변성을 방지하고, 무독성의 식품용 소재에 응용하기에 가장 유용한 방법이라고 판단 되어, 유자씨 추출에 적용하였다.

나노에멀젼이란 $500 \mathrm{~nm}$ 이하의 매우 작고 균일한 크기 의 입자를 가지는 콜로이드 상태를 일컬으며(Katouli 등, 2018), 작은 크기 때문에 마이크로에멀젼과 비교하여 좀 더 투명한 외관을 가질 수 있다(Jo 등, 2014). 또한, 경구로 섭취하여 소화 시 체내 흡수율에 증가되는 장점이 있어 이를 이용한 식품, 음료, 화장품 및 제약 산업 등 다방면에 서 응용이 이루어지고 있는 실정이다. 일반적으로 나노에 멀젼을 제조하는 방법으로는 저에너지(low-energy) 에멀 젼화 방법과 고에너지(high-energy) 에멀젼화 방법으로 크 게 분류할 수 있다(Silva 등, 2015). 특히 높은 파쇄 에너지를 필요로 하는 고에너지 에멀젼화 방법은 초음파 균질기 (ultrasonic homogenizer) 또는 초고압 균질기(high pressure homogenizer) 등과 같은 유화장치를 이용하여 나노에멀젼 을 제조한다고 보고되었다(Jafari 등, 2006; Jo 등, 2014).
초음파 균질기를 이용한 에멀젼화 방식은 유화제의 존재 하에 초음파 에너지를 가할 때 생성되는 내파 진공 거품으 로 인해 용매 주위에 큰 충격파가 발생되고, 높은 속도의 추진력으로 인해 나노에멀젼이 만들어지게 된다(Maa와 Hsu, 1999).

본 연구에서는 기존에 폐기되고 있는 유자씨를 효율적 으로 활용하기 위하여, 초임계 이산화탄소 추출 방법을 이용하여 유자씨에서 유자 오일을 추출하였고, 유자 오일 과 유자즙을 이용하여 oil-in-water(O/W) 유자 나노에멀젼 을 개발하였다. 또한, 유자 나노에멀젼의 안정성을 향상시 키기 위해 키토산으로 코팅하였다. 유자가 가지고 있는 항 균 특성을 평가하기 위해 유자즙, 유자 나노에멀젼 및 키토 산 코팅 유자 나노에멀젼의 항균 특성을 disk diffusion법과 현탁도법을 이용하여 Staphylococcus aureus와 Escherichia coli에 대한 항균효과를 비교하였다.

\section{재료 및 방법}

\section{실험재료}

유자 종자는 전남 고흥군에 있는 농업회사법인(주세일 식품(Goheung, Korea)에서 구매하였으며, 냉압착 방식으 로 제조한 유자즙은 고려자연식품(주(Jeonju, Korea)에서 제 공 받았다. 키토산(chitosan, medium molecular weight), tween 80 및 citric acid는 Sigma-Aldrich Co.(St. Louis, MO, USA)에서 구매하였다. Acetic acid(99.7\%)는 Junsei Chemical(Tokyo, Japan)에서 구입하였다.

\section{유자 종자 오일 추출}

유자 종자를 깨끗하게 세척하고, 동결건조기를 이용하여 48시간 동결건조(Freeze Dryer, ILShin BioBase, Gwangju, Korea)시킨 후 분쇄기에 넣고 갈아 분말을 만들고, 초임계 추출 장비((재)전남생물산업진흥원 나노바이오연구센터, Jangseong, Korea)를 이용하여 추출하였다. 초임계 이산화 탄소 추출 조건에서 압력은 280-400 bar이고, 분리조 온 도는 $40^{\circ} \mathrm{C}$, 추출조 온도는 $50^{\circ} \mathrm{C}$ 로 하였으며, retention time 은 180-240 $\min$ 으로 하였다.

\section{유자 나노에멀젼 제조}

유자즙을 membrane filter를 사용하여 잔여물을 걸러낸 다음 이를 연속상으로 사용하였다. 유자즙과 tween 80 을 혼합하여 30 분간 교반시킨 후, 유자오일을 연속상인 유자 즙에 한 방울씩(dropwise) 떨어뜨려 넣어주었다. 이를 1시 간 동안 교반 후, 15 분 동안 $12,000 \mathrm{rpm}$ 으로 high speed homogenizer(T18 digital ULTRA-TURRAX ${ }^{\circledR}$, IKA, Königswinter, Germany)를 이용하여 균질 처리하고, ultrasonic homogenizer(VCX-750, Sonics \& Materials Inc., Sandy 
Hook, CT, USA)를 이용하여 주파수 $20 \mathrm{kHz}$, 출력 $150 \mathrm{~W}$, amplitude $30 \%$ 조건에서 온도 상승을 방지하기 위해 ice bath 내에서 20 분 동안 초음파 균질 처리를 하였다. 키토산 코팅된 나노에멀젼 제조를 위하여, $1 \%(\mathrm{w} / \mathrm{v})$ acetic acid를 넣은 증류수 $(\mathrm{pH} 3.0)$ 에 $1 \%(\mathrm{w} / \mathrm{v})$ 키토산을 녹여 용액으로 만들었다. 균질화된 나노에멀젼과 $1 \%$ 키토산 용액을 $1: 1$ 의 비율로 나노에멀젼을 키토산 용액에 dropwise로 떨어 뜨려 코팅을 하였고, 최종적으로 ultrasonic homogenization을 15 분간 실시해 유자 에멀젼 입자의 미세화 및 안정화를 도모하였다.

\section{입자크기 및 입자분포도 측정}

유자 나노에멀젼의 평균 입자크기, 분포도(polydispersity, PDI) 및 제타전위(zeta potential)는 dynamic light scattering 원리를 이용하여 Zetasizer Nano-ZS90(Malvern Instruments, Worcestershire, UK)를 이용하여 분석하였다. 나노에멀젼 $2 \mathrm{~mL}$ 를 취하여 3 회 반복 측정하여 평균값으로 나타내었 다. 유자 나노에멀젼의 저장 안정성을 확인하기 위해 제조 후 측정한 유자 나노에멀젼의 평균 입자크기와 $4^{\circ} \mathrm{C}$ 에서 2 주간 저장 후 측정한 평균 입자크기를 비교하였으나, 유 의적인 차이가 없어 $4^{\circ} \mathrm{C}$ 에서 2 주간 저장 후 측정한 결과값 을 사용하였다.

\section{Transmission electron microscopy(TEM)에 의 한 입자 형태 관찰}

유자즙, 초음파 처리한 유자즙, 유자 나노에멀젼 및 키 토산 코팅 유자 나노에멀젼 입자의 형태적 특성은 TEM(Tecnai G2 F30, FEI Company, Eindhoven, Netherlands) 장비를 이용하여 관찰하였다. 나노에멀젼 샘플 용 액 한 방울을 탄소 피복 그리드 상에 침착시키고 1 분 동안 유지시켰다. 과량의 용액을 여과지로 제거하였다. $2 \%(\mathrm{w} / \mathrm{w})$ 인산 텅스텐산 용액 한 방울을 적용하여 약 1 분 동안 샘플을 염색하였다. TEM 이미지를 얻기 위하여, 모 든 샘플을 실온에서 12 시간 이상 건조시킨 후 관찰하였다.

\section{항균력 평가}

\section{Disk diffusion법}

유자즙, 초음파 처리 유자즙 및 유자 나노에멀젼의 항균 력을 확인하기 위하여 disk diffusion법(Lee와 Lee, 2017)을 사용하였다. 각각의 균주 배양액은 $600 \mathrm{~nm}$ 에서 흡광도를 측정하여 균의 농도를 $10^{8} \mathrm{CFU} / \mathrm{mL}$ 로 희석하여 사용하였 다. 액체 상태인 tryptic soy agar(TSA, Difco Laboratories Inc., Detroit, MI, USA) 배지 $10 \mathrm{~mL}$ 를 분주하여 만들어 놓은 한천 배지에 $100 \mu \mathrm{L}$ 의 세균현탁액을 접종 후 균일하 게 도말 한 뒤 실온에 잠시 보관하였다. 멸균된 $8 \mathrm{~mm}$ paper
disk(Advantec Co., Tokyo, Japan)에 $50 \mu \mathrm{L}$ 의 유자즙 및 각 각의 유자 나노에멀젼을 분주한 후, 도말 된 배지 표면에 부착시킨 다음 $37^{\circ} \mathrm{C}$ 에서 24 시간 배양하였다. 배양한 후 disk 주위의 clear zone의 생성 유무와 직경(diameter)의 크 기를 측정하여 항균력을 확인 및 비교하였다. 항균력 평가 를 위해 사용한 균주는 대표적인 식품 병원성 균주인 Staphylococcus aureus(S. aureus)와 Escherichia coli(E. coli) 를 사용하였고, 각 균주에 대하여 항균력 측정 실험은 3 반 복 하여 평균값을 구하였다.

\section{현탁도법}

저장 온도 및 시간에 따른 초음파 처리 유자즙, 유자 나노에멀젼 및 키토산 코팅 유자 나노에멀젼의 항균력을 평가하기 위해 현탁도법(Woo 등, 2018)을 이용하였다. 4 $\mathrm{mL}$ 의 tryptic soy broth(TSB, Sigma Aldrich Co., St. Louis, $\mathrm{MO}, \mathrm{USA}$ ) 배지에 $500 \mu \mathrm{L}$ 의 유자즙, 유자 나노에멀젼 및 키토산 코팅 유자 나노에멀젼 용액을 접종하고, $500 \mu \mathrm{L}$ 의 세균 현탁액 $\left(10^{8} \mathrm{CFU} / \mathrm{mL}\right)$ 을 접종 후 $25^{\circ} \mathrm{C}$ 와 $10^{\circ} \mathrm{C}$ 온도 조건에서 혼탕 배양 $(110 \mathrm{rpm})$ 하였다. 배양 후 총 12시간 동안 2시간 간격으로 배양액 시료를 채취하여 UVspectrophotometer(Mecasys Co. Ltd., Daejeon, Korea)를 이용 해 $640 \mathrm{~nm}$ 에서 흡광도를 측정하였다. Negative control로는 멸균된 phosphate-buffered saline(PBS, pH 7.4, Life Technologies Co., Paisley, UK), positive control로는 $1 \mathrm{mg} / \mathrm{mL}$ 의 Ampicillin(Sigma-Aldrich Co.)을 사용하였다. 현탁도법에 의한 항균력 평가는 S. aureus와 E. coli를 사용하였고, 각 균주에 대해 3 반복 하여 평균값을 구하였다.

\section{통계처리}

모든 분석 결과는 3 반복으로 실험한 평균값이며, 각 분 석결과에 대한 통계분석은 SPSS 통계프로그램(Statistics Ver. 24.0 IBM, Chicago, IL, USA)을 이용하였고, Duncan's multiple range test를 이용하여 평균치 간의 유의성을 $\mathrm{p}<0.05$ 수준에서 실시하여 각 시료간의 유의적인 차이를 검증하였다.

\section{결과 및 고찰}

\section{유자 나노에멀젼과 키토산 코팅 유자 나노에멀젼의 특성}

유자씨를 건조하고, 초임계 이산화탄소 추출 방식으로 추출한 유자 오일을 $\mathrm{O} / \mathrm{W}$ (oil-in-water) 유자 나노에멀젼의 오일상으로 이용하였다. 냉압착 방식으로 얻은 유자즙은 여과하여 맑은 상태로 준비해 유자 나노에멀젼의 연속상 으로 사용하였다. Fig. 1(A)에서 보는 것과 같이 $\mathrm{O} / \mathrm{W}$ 유자 나노에멀젼의 구조는 연속상인 유자즙에 유화제인 tween 
(A)

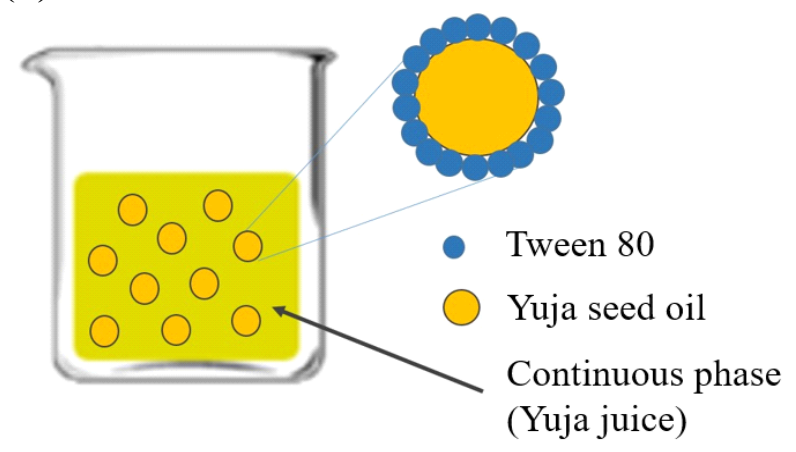

(B)

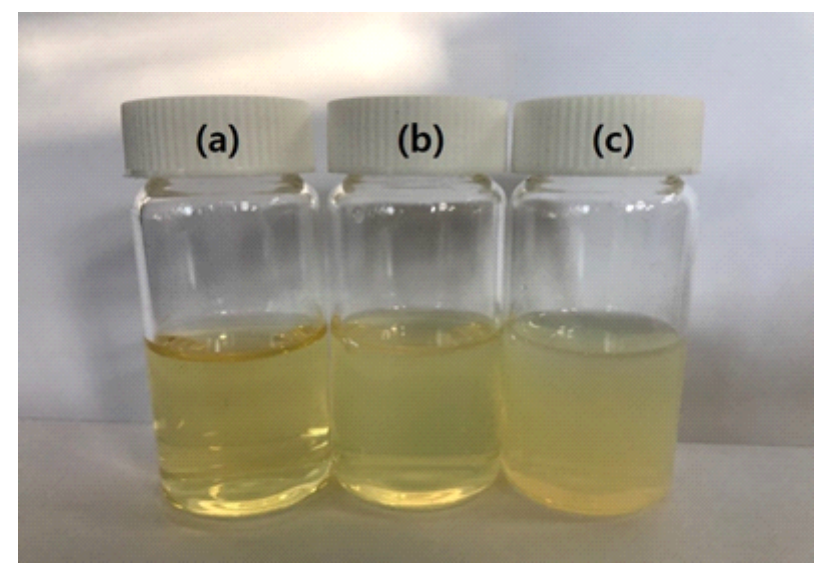

Fig. 1. Schematic illustration of (A) 'Yuja' nanoemulsion and (B) pictures of ultrasonic homogenization-treated 'Yuja' Juice (a), 'Yuja' nanoemulsion (b), and chitosan-coated 'Yuja' nanoemulsion (c).

80 이 표면을 둘러서 감싸고 있는 유자씨 오일의 액적 (droplet)이 균일하게 분산되어 있으며, 안정한 상태의 에 멀젼을 형성하고 있다. Fig. 1(B)는 유자즙, 유자 나노에멀 젼 및 키토산 코팅 유자 나노에멀젼 용액의 사진으로 그림 에서 보는 것과 같이 유자즙은 매우 투명하고 맑은 용액이 었으며, 유자 나노에멀젼도 미색의 맑은 상태가 관찰되었 다. 하지만 $1 \%$ 키토산으로 코팅한 시료의 경우 키토산 용액의 영향으로 조금 더 탁하고, 옅은 미색의 유자 나노 에멀젼을 관찰할 수 있었다. 초음파 처리를 한 유자즙은 평균 입자의 크기가 $145.6 \pm 0.29 \mathrm{~nm}$ 의 크기로 관찰되었으 며, $\mathrm{PDI}$ 는 0.288 로써 입자가 매우 고르게 분산되어 있음을 관찰하였다. 유자씨 오일과 유자즙을 이용하여 제조한 유 자 나노에멀젼은 평균 입자크기가 $212.8 \pm 0.08 \mathrm{~nm}$ 로 측정 되었으며, PDI는 0.075 로써 입자가 상당히 고르게 분산되 어 있음을 알 수 있었다(Fig. 2A). 키토산 코팅 유자 나노에 멀젼의 경우 입자의 크기가 $79.5 \pm 0.37 \mathrm{~nm}$ 로 측정이 되어 유자 나노에멀젼의 평균 입자크기 보다 유의적으로 $(\mathrm{p}<0.05)$
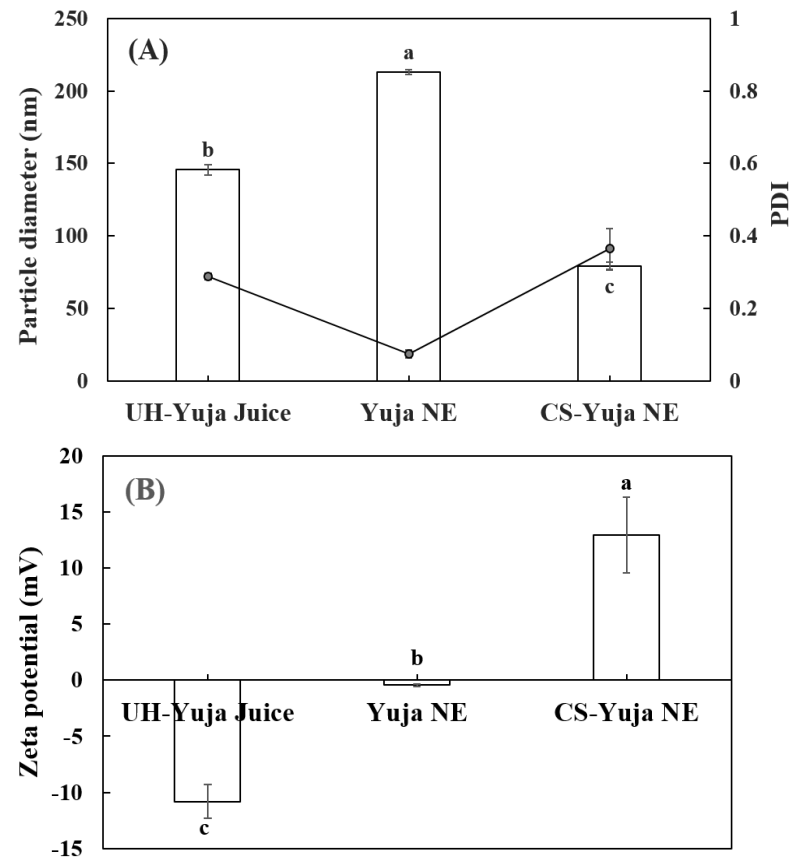

Fig. 2. (A) Particle diameter and polydispersity index and (B) zeta potential of ultrasonic homogenization-treated 'Yuja' juice (UH'Yuja' juice), 'Yuja' nanoemulsion ('Yuja' NE), and chitosancoated 'Yuja' NE (CS-'Yuja' NE).

${ }^{a-c}$ Different letters indicate a significant difference at $p<0.05(n=3)$.

줄어든 반면, PDI는 0.365 로 유자 나노에멀젼이나 초음파 처리 유자즙에 비해 다소 높게 측정되었다. Fig. 2(B)에서 보는 것과 같이 제타 전위의 경우, 초음파 처리한 유자즙 은 $-9.26 \mathrm{mV}$ 로 나타났으며, 유자 나노에멀젼의 경우는 비이온성 계면활성제인 tween 80 에 의해 $-0.35 \mathrm{mV}$ 로 0 에 가까운 값이 관찰되었다. 하지만, 키토산 코팅을 한 유자 나노에멀젼의 경우는 $+18.0 \mathrm{mV}$ 로 양전하 값으로 관찰되 었다. 이러한 결과는 음전하인 유자즙에 양이온의 키토산 이 정전기적 인력으로 인해 강하게 반응하여 입자를 형성 하면서 유자 나노에멀젼보다 키토산 코팅 유자 나노에멀 젼이 더 작은 입자를 형성할 수 있었다고 판단된다. 이전 논문에서도 키토산으로 코팅된 나노에멀젼 입자의 크기 가 코팅전 에멀젼의 입자보다 크기가 작아지는 것을 관찰 할 수 있었으며, 이는 양이온인 키토산과 음이온으로 하전 된 나노에멀젼의 정전기적 인력에 의해 입자가 코팅되면 서 수축되어 크기가 줄어드는 현상을 볼 수 있다고 보고되 었다( $\mathrm{Li}$ 등, 2016).

$\mathrm{PDI}$ 는 입자의 분산정도를 나타내는 지표로써 범위는 0 에서 1 내로 표시되는데, PDI가 0.3 이하일 시 단분산상 형태를 의미하고, 0.3 에서 0.6 사이는 중분산상 형태, 0.6 이상은 다분산상 형태로 입자가 분포해 있음을 의미한다 (Jo 등, 2016). Fig. 2에서 보는 바와 같이 유자즙과 유자 
나노에멀젼의 경우 매우 안정적이고, 균일한 입자의 분포 를 관찰할 수 있었다. Li 등(2016)의 연구에서, 나노에멀젼 은 온도의 변화나, 시간이 지남에 따라 입자의 안정성이 떨어져 에멀젼의 상이 분리되는 현상을 쉽게 관찰할 수 있으나(Li 등, 2016), 본 연구에서 개발한 유자 나노에멀젼 과 키토산 코팅 유자 나노에멀젼의 경우에도 우수한 안정 성을 보이며, 상 분리(phase separation)와 같은 불안정성은 관찰되지 않았다.

\section{TEM을 이용한 유자 나노에멀젼 입자 형태 관찰}

유자즙, 초음파균질화된 유자즙, 유자 나노에멀젼 및 키토산 코팅 유자 나노에멀젼의 입자 형태를 투과전자현 미경(TEM)을 이용하여 입자의 형태와 분포를 관찰하였 다. Fig. 3(A)에서 보는 것과 같이 유자즙의 경우 입자크기 가 $500-1,000 \mathrm{~nm}$ 사이의 큰 입자들과 $200 \mathrm{~nm}$ 이하의 작은 입자들이 응집되어 있는 모습을 보이고 있다. 하지만 초음 파 균질 처리를 통해 입자의 크기가 $200 \mathrm{~nm}$ 수준에서 응집
없이 균일하게 분포된 것을 관찰할 수 있었다(Fig. 3B). 유자 나노에멀젼의 입자 형태는 둥근것과 길쭉한 모양의 입자도 다소 관찰이 되었으나(Fig. $3 \mathrm{C}$ ), 키토산 코팅 유자 나노에멀젼의 입자들은 대체로 둥글고, 입자의 크기가 작 았으며 전체적인 균일한 분포도를 보이는 것으로 관찰되 었다(Fig. 3D).

\section{Disk diffusion법에 의한 항균효과}

유자즙과 초음파 처리한 유자즙, 유자 나노에멀젼의 항 균효과를 disk diffusion법을 이용하여 disk 주변에 생성된 inhibition zone diameter를 측정한 결과를 Fig. 4에 나타내 었다. 유자즙, 초음파처리 유자즙 및 유자 나노에멀젼은 E. coli에 대해서 각각 $10.56 \pm 0.95 \mathrm{~mm}, 14.12 \pm 2.17 \mathrm{~mm}$ 및 $13.49 \pm 0.78 \mathrm{~mm}$ 의 clear zone을 형성하였으며, 특히 초음파 처리 후 E. coli 균에 대한 유자즙의 항균효과가 크게 증가 하는 결과를 얻었다. 한편, S. aureus에 대해서는 각각 $14.93 \pm 0.3 \mathrm{~mm}, 15.20 \pm 0.46 \mathrm{~mm}$ 및 $12.22 \pm 0.74 \mathrm{~mm}$ 의 clear

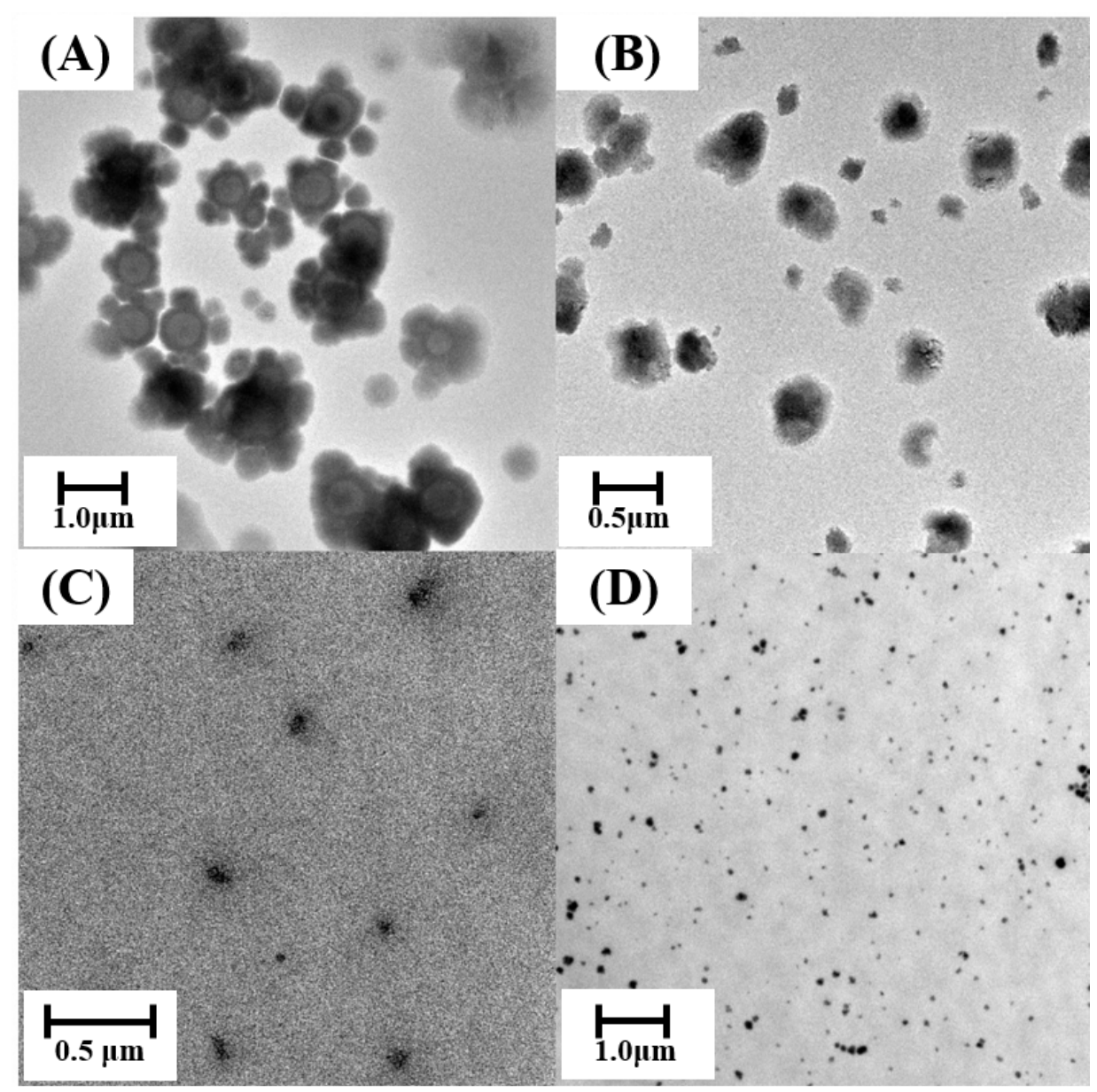

Fig. 3. TEM images of (A) original 'Yuja' juice, (B) ultrasonic homogenization-treated 'Yuja' juice, (C) 'Yuja' nanoemulsion, and (D) chitosan-coated 'Yuja' nanoemulsion. 


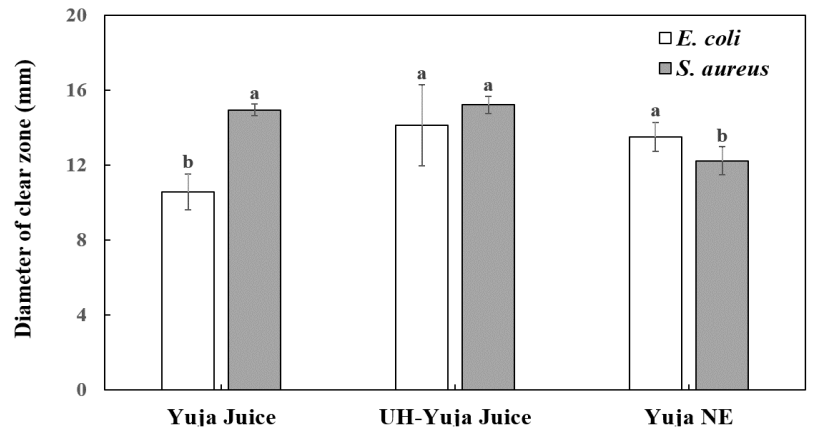

Fig. 4. Diameter of clear zone by 'Yuja' juice, ultrasonic homogenization treated 'Yuja' juice (UH-'Yuja' Juice), and 'Yuja' nanoemulsion ('Yuja' NE) against Escherichia coli and Staphylococcus aureus.

${ }^{a-b}$ Different letters indicate a significant difference at $\mathrm{p}<0.05(\mathrm{n}=3)$.

zone을 형성하는 것으로 관찰되어 유자즙과 초음파 처리 유자즙의 경우는 E. coli 균에 비해S. aureus 균에 대하여 좀 더 높은 항균력을 보이는 결과를 얻었다. 특히 15 분간 초음파 처리한 유자즙의 경우가 처리하지 않은 유자즙에 비해 항균성이 높은 것은 초음파 처리에 의해 뭉쳐 있었던 유자즙의 입자들이 균일하게 분산되어 균에 대한 접촉면 이 증가하였기 때문이며, 또한 유자즙에 함유된 헤스페리 딘이나 리모넨과 같은 항균성 물질들의 용해도가 증가하 면서 활성이 향상되었을 것으로 사료된다. 유자 추출물을 이용한 항균활성에 관한 이전의 연구에서도 열수 추출과 에탄올 추출로 얻은 유자과즙 추출물은 $S$. aureus, $S$. epidermidis 및 E. coli에 대해서 강한 항균력이 있다고 보고 되었다(Lee와 Lee, 2017).

\section{현탁도법에 의한 항균효과}

Fig. 5 는 $25^{\circ} \mathrm{C}$ 와 $10^{\circ} \mathrm{C}$ 에서 12 시간 동안 저장하면서 $S$. aureus 균에 대한 초음파 처리한 유자즙, 유자 나노에멀젼 및 키토산 코팅 유자 나노에멀젼의 항균효과를 현탁도법 을 이용하여 $\mathrm{OD}$ (optical density) 값으로 나타낸 결과이다. $25^{\circ} \mathrm{C}$ 에서 저장한 경우, 초음파처리 유자즙이 유자 나노에 멀젼보다 항균효과가 높게 나타났고, 키토산 코팅 유자 나노에멀젼이 가장 우수한 항균효과를 보였다(Fig. 5A). 또한, 초음파 처리 유자즙과 유자 나노에멀젼은 6시간 이 후부터 $\mathrm{OD}$ 값이 유의적으로 $(\mathrm{p}<0.05)$ 증가하는 결과를 보 였으나, 대조군인 PBS 용액에 비해서는 매우 낮은 수준으 로 관찰되었다. 키토산 코팅 유자 나노에멀젼의 경우에는 가장 높은 항균력을 지속하는 것으로 관찰되었는데, 이는 키토산 자체도 항균 특성을 가지고 있기 때문에 유자에 의한 항균력과 시너지 효과가 작용하였다고 판단된다 (Jeong 등, 2011). 저온 저장 온도인 $10^{\circ} \mathrm{C}$ 에서는 $25^{\circ} \mathrm{C}$ 와 비교하여 $\mathrm{OD}$ 값이 전체적으로 약 $1 / 4$ 수준으로 나타났으
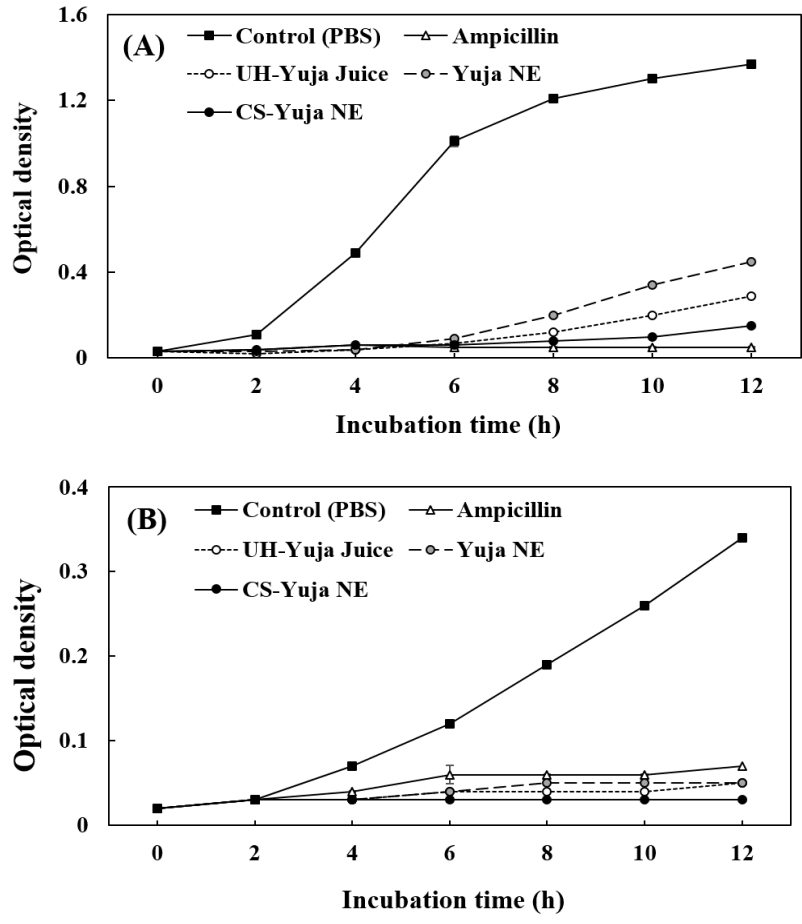

Fig. 5. The inhibition effect of negative control (PBS), positive control (Ampicillin), ultrasonic homogenization treated-'Yuja' Juice (UH-'Yuja' juice), 'Yuja' nanoemulsion ('Yuja' NE), and chitosancoated 'Yuja' NE (CS-'Yuja' NE) against Staphylococcus aureus (A) at $25^{\circ} \mathrm{C}$ and (B) at $10^{\circ} \mathrm{C}$ over different incubation time.

며, 대조군을 제외하고는 6시간 이후에 모든 시료에서 유 의적인(p>0.05) 변화는 없었다(Fig. $5 \mathrm{~B})$. 특히, $10^{\circ} \mathrm{C}$ 에서는 positive control인 Ampicillin 보다도 유자즙, 유자 나노에 멀젼 및 키토산 코팅 유자 나노에멀젼의 항균효과가 높은 결과를 보였다.

Fig. 6 은 $25^{\circ} \mathrm{C}$ 와 $10^{\circ} \mathrm{C}$ 에서 12 시간 동안 저장하면서 $E$. coli 균에 대한 초음파 처리한 유자즙, 유자 나노에멀젼 및 키토산 코팅 유자 나노에멀젼의 항균효과를 나타낸 결과이다. E. coli 균에 대한 항균 효과는 S. aureus 균에 대한 결과와 유사한 경향성을 보이고 있는데, $25^{\circ} \mathrm{C}$ 에서 대조군은 2시간 이후에 $\mathrm{OD}$ 값이 급격이 상승하였고, 대조 군을 제외한 다른 샘플들의 경우 6시간이 이후 서서히 증가하는 결과를 얻었다(Fig. 6A). E. coli 균의 경우에도 키토산 코팅 유자 나노에멀젼의 경우가 가장 항균 활성이 높은 것으로 관찰되었다. $10^{\circ} \mathrm{C}$ 에서는 대조군을 제외하고, 12 시간 이내에 각 시료의 $\mathrm{OD}$ 값은 거의 변화가 없었다 (Fig. 6B). 키토산과 자몽종자추출물을 이용하여 살균소독 표준 균주로 S. aureus와 E. coli에 대한 항균활성을 검토한 연구에서 키토산은 미생물의 성장에 필요한 미량원소나 금속이온들에 킬레이트로 작용하여 생육을 억제하거나, 직접적으로 세포막에 침투하여 세포막을 손상시킴으로써 

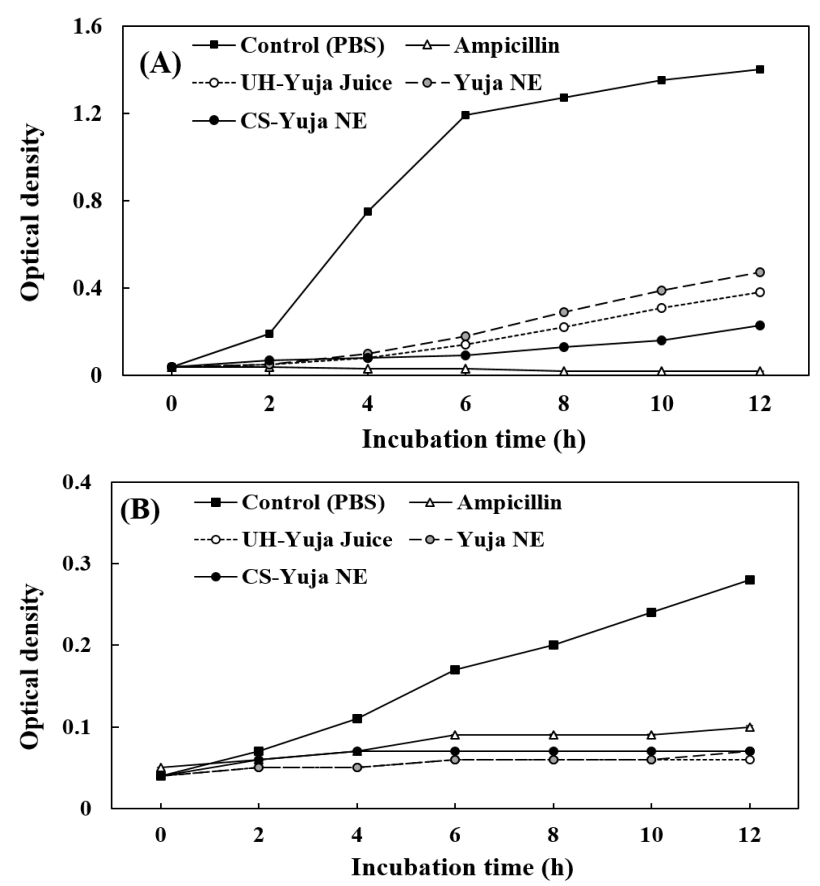

Fig. 6. The inhibition effect of negative control (PBS), positive control (Ampicillin), ultrasonic homogenization treated-'Yuja' juice (UH-'Yuja' Juice), 'Yuja' nanoemulsion ('Yuja' NE), and chitosancoated 'Yuja' NE (CS-'Yuja' NE) against Escherichia coli (A) at $25^{\circ} \mathrm{C}$ and (B) at $10^{\circ} \mathrm{C}$ over different incubation time.

항균활성을 나타내는 것으로 보고되었다(Jeong 등, 2011).

\section{요 약}

본 연구에서는 초임계 이산화탄소 추출 방법을 이용하 여 유자씨에서 오일을 추출하였고, 냉압착 방식으로 추출 된 유자즙을 여과 후 연속상으로 이용하였으며, 초음파 균질 처리를 통해 유자 나노에멀젼을 제조하였다. 유자 나노에멀젼의 평균 입자크기는 $145.6 \mathrm{~nm}$ 인 반면, 키토산 코팅 유자 나노에멀젼의 입자크기는 키토산의 양이온과 유자 나노에멀젼의 음이온이 정정기적 인력에 의한 수축 으로 인해 $79.5 \mathrm{~nm}$ 로 크게 줄어드는 결과를 얻었다. Disk diffusion법에 의한 항균력 평가 결과에서 E. coli 균주에 대한 항균력은 초음파 균질 처리한 유자즙이 처리 전의 유자즙에 비해 경우에 약 $34 \%$ 가 증가하는 결과를 보였는 데, 이는 초음파 균질 처리에 의해 응집되어 있던 유자즙 입자들이 작고 균일하게 분산되면서 표면적의 증가와 세 포벽에 감싸 있던 항균성 물질들이 더 많이 노출 및 용해 되면서 이들이 E. coli 균주에 접촉하게 될 확률이 증가하 였기 때문으로 사료되었다. 현탁도법에 의한 항균력 평 가에서는 $25^{\circ} \mathrm{C}$ 에서 유자즙, 유자 나노에멀젼 및 키토산 코팅 유자 나노에멀젼 시료들이 S. aureus와 E. coli 균주
에서 모두 우수한 항균효과를 보여주었으며, 항균력은 12시간까지도 지속되는 결과를 얻었다. 이처럼 유자산업 에서 활용이 미비하거나 폐기되는 유자즙과 유자씨를 활용한 항균활성이 우수한 나노에멀젼은 추후 기능성 식품 또는 천연 항균제의 개발에 대한 적용 가능성을 보여주었다.

\section{감사의 글}

이 논문은 2018년도 전라북도 선도기업 기술개발역량 강화 지원사업 지원에 의하여 연구되었음.

\section{Conflict of interests}

The authors declare no potential conflict of interest.

\section{ORCID}

Seo A Jung https://orcid.org/0000-0002-4136-5829

Gye Hwa Shin https://orcid.org/0000-0002-1891-9053

\section{References}

Cho YJ, Lee SB, Lee JK, Kwon YJ. Preparation of nanoemulsions containing curcumin by high pressure homogenization. Food Eng Prog, 18, 341-347 (2014)

Jafari SM, He Y, Bhandari B. Nano-emulsion production by sonication and microfluidization-A comparison. Int J Food Prop, 9, 475-485 (2006)

Jeong EJ, Park LY, Park HJ, Lee SH. Antibacterial effect of chitosan and grape seeds extracts against Staphylococcus aureus and Escherichia coli. J Chitin Chitosan, 16, 27-32 (2011)

Jo WT, Hidajat MJ, Park JB, Ji SH, Noh JH, Kim HH. Extraction and characterization of essential oil of Korean orange peel obtained from supercritical $\mathrm{CO}_{2}$ extraction. Korean Soc Biotechnol Bioeng J, 33, 227-236 (2018)

Jo YJ, Kim HY, Kwon YJ. Influence of biopolymer emulsifier on the characteristics of curcumin nanoemulsions. Food Eng Prog, 20, 321-327 (2016)

Kang SK, Jang MJ, Kim YD. A study on the flavor constituents of the citron (Citrus junos). Korean J Food Preserv, 13, 204-210 (2006)

Katouli M, Polychminatou V, Tzia C. Optimization of water in olive oil nano-emulsions compositions with bioactive compounds by response surface methodology. LWT-Food 
Sci Technol, 89, 740-748 (2018)

Kim DS, Kim DH, Oh MJ, Lee KG, Kook MC, Park CS. Antiaging and whitening activities of ethanol extract of yuza (Citrus junos Sieb eib. ex Tanaka) by-product. J Soc Cosmet Scientists Korea, 36, 137-143 (2010)

Lee JE, Kim KM, Kim JS, Kim GC, Choi SY, Kim SB. Chemical compositions and antioxidant activities depending on cultivation methods and various parts of yuza. Koean J Food Preserv, 24, 802-812 (2017)

Lee SH, Choen JK, Ju CS. Effective extractions and chemical components of citron seed extracts by supercritical carbon dioxide. Food Eng Progr, 6, 158-164 (2002)

Lee SH, Lee MS. The study of physiological and antimicrobial activities on the Citrus junos extracts with its textures and skin. J Korea Acad Industr Coop Soc, 18, 67-74 (2017)

Li JL, Hwang IC, Chen XG, Park HJ. Effects of chitosan coating on curcumin loaded nano-emulsion: Study on stability and in vitro digestibility. Food Hydrocolloids,
60, 138-147 (2016)

Maa YF, Hsu CC. Performance of sonication and microfluidization for liquid-liquid emulsification. Pharm Dev Technol, 4, 233-240 (1999)

Silva EK, Rosa MTM, Meireles MAA. Ultrasound-assisted formation of emulsions stabilized by biopolymers. Curr Opin Food Sci, 5, 50-59 (2015)

Woo N, Lee HS, Ko SH. Antimicrobial activities of native plant extracts and development of antibacterial container with extracts. J East Asian Soc Diet Life, 28, 231-238 (2018)

Yang HS, Hwang SJ, Lee SH, Eun JB. The fermentation characteristics and sensory characteristics of Makgeolli with dried citron (Citrus junos Sieb. ex Tanaka) peel. Korean J Food Sci Technol, 43, 603-610 (2011)

Yoo KM, Hwang IK. In vitro effect of yuza (Citrus junos Sieb. ex Tanaka) extracts on proliferation of human prostate cancer cells and antioxidant activity. Korean J Food Sci Technol, 36, 339-344 (2004) 